\section{Regards sur l'économie allemande}

Bulletin économique du CIRAC

$110 \mid 2013$

Varia

\title{
Médias et politique
}

JUNGHERR Andreas, SCHOEN Haral, Das Internet in Wahlkämpfen.

Konzepte, Wirkungen und Kampagnenfunktionen

\section{(2) OpenEdition}

Journals

Édition électronique

URL : http://journals.openedition.org/rea/4604

DOI : $10.4000 /$ rea.4604

ISSN : 1965-0787

Éditeur

CIRAC

Édition imprimée

Date de publication : 15 octobre 2013

Pagination : $39-40$

ISSN : 1156-8992

Référence électronique

"Médias et politique », Regards sur l'économie allemande [En ligne], 110 | octobre 2013, mis en ligne le 16 octobre 2013, consulté le 22 septembre 2020. URL : http://journals.openedition.org/rea/4604 ; DOI : https://doi.org/10.4000/rea.4604

Ce document a été généré automatiquement le 22 septembre 2020.

(c) CIRAC 


\section{Médias et politique}

JUNGHERR Andreas, SCHOEN Haral, Das Internet in Wahlkämpfen.

Konzepte, Wirkungen und Kampagnenfunktionen

\section{RÉFÉRENCE}

JUNGHERR Andreas, SCHOEN Haral, Das Internet in Wahlkämpfen. Konzepte, Wirkungen und Kampagnenfunktionen, Springer Fachmedien, Wiesbaden, 2013, 188 p.

1 En comparaison des Etats-Unis, les partis politiques allemands misent peu encore sur les opportunités d'Internet. Il est vrai que les blogs ou les réseaux sociaux ne sont guère reconnus comme vecteurs d'information établis et que, quand les partis y ont recours pour mener leur communication, c'est alors en obéissant aux critères classiques de l'information journalistique. C'est ce qu'il ressort de cet état des lieux commandité à deux chercheurs de l'université de Bamberg par la Fondation Konrad Adenauer (CDU). L'E-campaigning a encore de beaux jours devant lui; la campagne des élections européennes nous le dira... (ib) 